\title{
Early-Holocene greening of the Afro-Asian dust belt changed sources of mineral dust in West Asia
}

A Sharifi

LN Murphy

A Pourmand

AC Clement

Elizabeth A. Canuel

Virginia Institute of Marine Science

Follow this and additional works at: https://scholarworks.wm.edu/vimsarticles

Part of the Aquaculture and Fisheries Commons

\section{Recommended Citation}

Sharifi, A; Murphy, LN; Pourmand, A; Clement, AC; and Canuel, Elizabeth A., "Early-Holocene greening of the Afro-Asian dust belt changed sources of mineral dust in West Asia" (2018). VIMS Articles. 754. https://scholarworks.wm.edu/vimsarticles/754 
archives-ouvertes

\section{Early-Holocene greening of the Afro-Asian dust belt changed sources of mineral dust in West Asia}

Arash Sharifi, Lisa Murphy, Ali Pourmand, Amy Clement, Elizabeth Canuel, Abdolmajid Beni, Hamid Lahijani, Doriane Delanghe, Hesam Ahmady-Birgani

\section{- To cite this version:}

Arash Sharifi, Lisa Murphy, Ali Pourmand, Amy Clement, Elizabeth Canuel, et al.. Early-Holocene greening of the Afro-Asian dust belt changed sources of mineral dust in West Asia. Earth and Planetary Science Letters, Elsevier, 2018, 481, pp.30-40. <10.1016/j.epsl.2017.10.001>. <hal-01631411>

\section{HAL Id: hal-01631411 \\ https://hal-amu.archives-ouvertes.fr/hal-01631411}

Submitted on 6 Feb 2018

HAL is a multi-disciplinary open access archive for the deposit and dissemination of scientific research documents, whether they are published or not. The documents may come from teaching and research institutions in France or abroad, or from public or private research centers.
L'archive ouverte pluridisciplinaire HAL, est destinée au dépôt et à la diffusion de documents scientifiques de niveau recherche, publiés ou non, émanant des établissements d'enseignement et de recherche français ou étrangers, des laboratoires publics ou privés. 


\title{
Early-Holocene greening of the Afro-Asian dust belt changed sources of mineral dust in West Asia
}

\author{
Arash Sharifi $^{\mathrm{a}, *}$, Lisa N. Murphy ${ }^{\mathrm{b}}$, Ali Pourmand ${ }^{\mathrm{a}}$, Amy C. Clement ${ }^{\mathrm{b}}$, Elizabeth A. Canuel ${ }^{\mathrm{c}}$, \\ Abdolmajid Naderi Beni ${ }^{\mathrm{d}}$, Hamid A.K. Lahijani ${ }^{\mathrm{d}}$, Doriane Delanghe ${ }^{\mathrm{e}}$, \\ Hesam Ahmady-Birgani ${ }^{\mathrm{f}}$
}

a Neptune Isotope Laboratory (NIL), Department of Marine Geosciences, Rosenstiel School of Marine and Atmospheric Science, University of Miami, 4600

Rickenbacker Causeway, Miami, FL 33149-1098, USA

${ }^{\mathrm{b}}$ Rosenstiel School of Marine and Atmospheric Science (RSMAS), University of Miami, 4600 Rickenbacker Causeway, Miami, FL 33149-1098, USA

c Virginia Institute of Marine Science, College of William \& Mary, P.O. Box 1346, Gloucester Point, VA, USA

d Iranian National Institute for Oceanography and Atmospheric Science (INIOAS), Marine Geology Division, P.0. Box 14155-4781, Tehran, Iran

e Aix Marseille Univ., CNRS, IRD, Coll France, CEREGE, Europôle de l'Arbois, Aix en Provence, France

${ }^{\mathrm{f}}$ Faculty of Natural Resources, Urmia University, Urmia, Iran

\section{A R T I C L E I N F O}

\section{Keywords:}

Holocene of Iran

West Asia

Paleo-dust

$\mathrm{Sr}-\mathrm{Hf}-\mathrm{Nd}$ isotopes

atmospheric circulation

dust provenance

\begin{abstract}
A B S T R A C T
Production, transport and deposition of mineral dust have significant impacts on different components of the Earth systems through time and space. In modern times, dust plumes are associated with their source region(s) using satellite and land-based measurements and trajectory analysis of air masses through time. Reconstruction of past changes in the sources of mineral dust as related to changes in climate, however, must rely on the knowledge of the geochemical and mineralogical composition of modern and paleodust, and that of their potential source origins. In this contribution, we present a 13,000-yr record of variations in radiogenic $\mathrm{Sr}-\mathrm{Nd}-\mathrm{Hf}$ isotopes and Rare Earth Element (REE) anomalies as well as dust grain size from an ombrotrophic (rain fed) peat core in NW Iran as proxies of past changes in the sources of dust over the interior of West Asia. Our data shows that although the grain size of dust varies in a narrow range through the entire record, the geochemical fingerprint of dust particles deposited during the lowflux, early Holocene period (11,700-6,000 yr BP) is distinctly different from aerosols deposited during high dust flux periods of the Younger Dryas and the mid-late Holocene (6,000-present). Our findings indicate that the composition of mineral dust deposited at the study site changed as a function of prevailing atmospheric circulation regimes and land exposure throughout the last deglacial period and the Holocene. Simulations of atmospheric circulation over the region show the Northern Hemisphere Summer Westerly Jet was displaced poleward across the study area during the early Holocene when Northern Hemisphere insolation was higher due to the Earth's orbital configuration. This shift, coupled with lower dust emissions simulated based on greening of the Afro-Asian Dust Belt during the early Holocene likely led to potential sources in Central Asia dominating dust export to West Asia during this period. In contrast, the dominant western and southwest Asian and Eastern African sources have prevailed during the mid-Holocene to modern times.
\end{abstract}

\section{Introduction}

West Asia, also referred to as the Middle East, is a climatically sensitive region that extends across the eastern Mediterranean Sea, Syria, Iraq, Iran and the Arabian Peninsula. Major Eurasian synoptic systems dominate over this portion of Asia, including the Siberian anticyclone (SA), the Indian Ocean Summer Monsoon (IOSM) and

\footnotetext{
* Corresponding author.

E-mail address: osharifi@miami.edu (A. Sharifi).
}

the Northern Hemisphere Summer Westerly Jet (NHSWJ) (Fig. 1). The convergence of these systems over West Asia and their interaction with external forcing such as solar irradiance and insolation, internal climate oscillations and anthropogenic forcing mechanisms make this region highly susceptible to abrupt shifts in climate regimes (e.g., Liu et al., 2015; McGee et al., 2014; Nagashima et al., 2011; Sharifi et al., 2015).

Mineral dust is an actively changing component of the biogeochemical (Moore et al., 2002) and hydrological cycles (Arimoto, 2001) and significantly influences the global radiation budget 


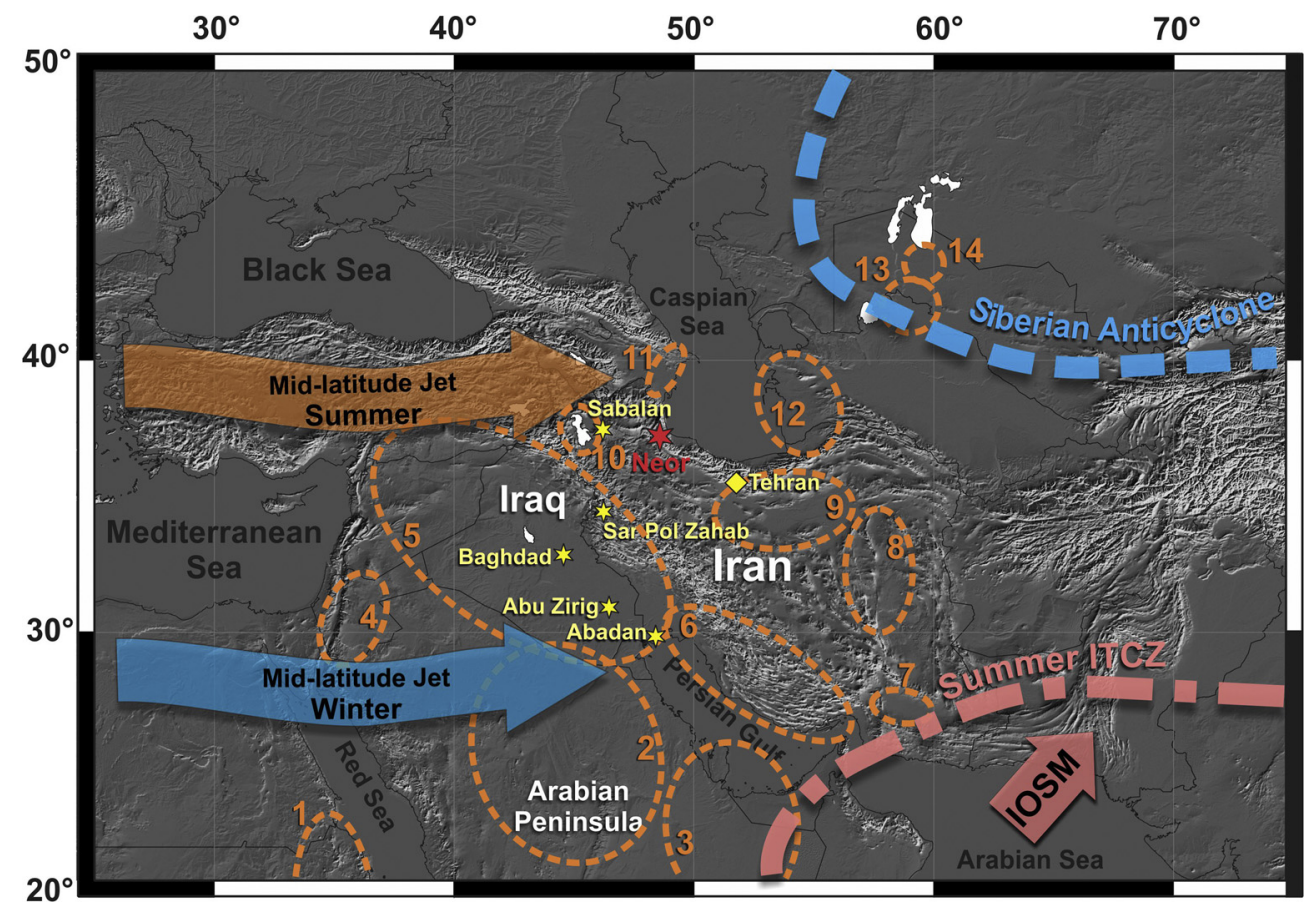

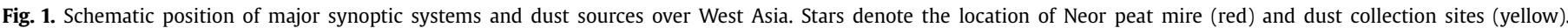

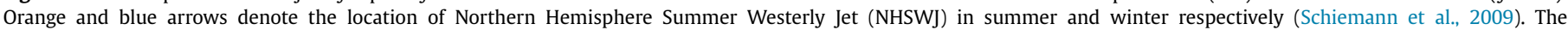

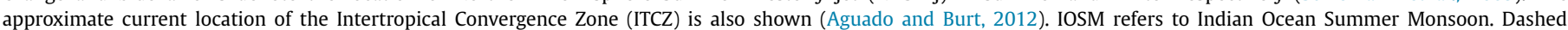

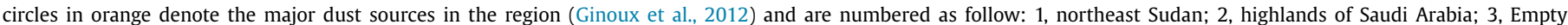

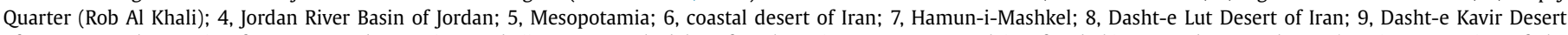

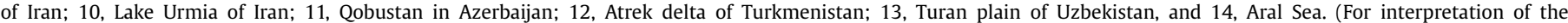
references to color in this figure legend, the reader is referred to the web version of this article.)

(Choobari et al., 2014; Miller and Tegen, 1998; Tegen and Lacis, 1996). The vast, arid and semi-arid areas across West Asia are part of the Afro-Asian "dust belt" and a major contributor to global atmospheric dust emissions (Prospero et al., 2002), with the Arabian Peninsula, Iraq and Syria contributing up to 20\% (Hamidi et al., 2013) in modern times. Large amounts of dust are delivered from these regions to the Persian Gulf, the Red Sea and the northern Indian Ocean (Goudie and Middleton, 2006; Littmann, 1991; Middleton, 1986; Pourmand et al., 2004; Prospero et al., 2002; Sirocko et al., 2000).

Paleo-dust records in lacustrine/marine sediments and ice cores suggest a strong link between mineral dust and the climate state. These records also indicate systematic variations in dust emission and transport in the past, changes in the amount of dust, dust typology and shifts in the source areas (Shao et al., 2011). The controlling mechanisms on atmospheric circulation and dust emission during the Holocene and the effect of climate variability on introducing new dust source regions in West Asia are poorly investigated. Previously, we reported a high-resolution, 13,000 record of mineral dust deposition at Neor Lake in NW Iran (Sharifi et al., 2015) that indicated changes in the composition of dust may have occurred during the last deglacial and the Holocene. In this contribution, we investigate this possibility by taking a novel approach of combining the results from paleo-dust grain size analysis with geochemical fingerprinting of modern and paleo-mineral dust using radiogenic $\mathrm{Sr}-\mathrm{Nd}-\mathrm{Hf}$ isotopes and Rare Earth Element (REE) anomalies measured in samples from Neor Lake peat complex. We further use climate simulation experiments to examine how variations in Holocene insolation influenced the dominant atmospheric circulation regimes over the region. We show changes in dust composition and flux in the interior of West Asia were likely coincident with changes in soil coverage across the Afro-Asian dust belt.

\section{Materials and methods}

\subsection{Study site}

Neor Lake $\left(37^{\circ} 57^{\prime} 37^{\prime \prime} \mathrm{N}, 48^{\circ} 33^{\prime} 19^{\prime \prime}\right.$ E) is a high-altitude ( 2,500 m.a.s.l.), seasonally-recharged lake in NW Iran (Fig. 1) and has hosted a peripheral peat complex since at least $13,000 \mathrm{yr}$ ago (Sharifi et al., 2015). The mean annual precipitation (30-yr average) recorded at the nearest meteorological station, $50 \mathrm{~km}$ to the north east of the lake at 1,332 m.a.s.l., exceeds $300 \mathrm{~mm}$. Mean annual temperature at the station is $15.4{ }^{\circ} \mathrm{C}$ and the mean maximum and minimum temperatures of the warmest and coldest months of the year are $25^{\circ} \mathrm{C}$ (July) and $-7.9^{\circ} \mathrm{C}$ (January), respectively. It is expected that Neor Lake experiences higher annual precipitation and lower temperature relative to the weather station since its elevation is $1,200 \mathrm{~m}$ higher than the station.

\subsection{Sampling}

A total of 41 samples with masses of about $1 \mathrm{~g}$ were taken from high and low dust intervals based on the XRF elemental profiles of a $7.5 \mathrm{~m}$ core from Neor Lake's peripheral peat complex (Sharifi et al., 2015). The samples span the last 13,000 yr according to 19 calibrated radiocarbon dates (Sharifi et al., 2015). Modern dust samples were collected upwind of Neor site at Abadan and Sar Pol Zahab meteorological stations (Fig. 1) from December 2011 to May 2012 using a Low Volume (LVS) Microcomputer Controlled Air Sampler (Micro PNS) at a rate of 2.3 cubic meters per hour for $168 \mathrm{~h}$ (Ahmady-Birgani et al., 2015).

\subsection{Radiogenic $\mathrm{Sr}-\mathrm{Nd}-\mathrm{Hf}$ isotope and the REE analyses}

Dried samples were homogenized in an agate mortar and ashed at $750^{\circ} \mathrm{C}$ for one hour. Approximately 0.015 to $0.035 \mathrm{~g}$ was fused 
Table 1

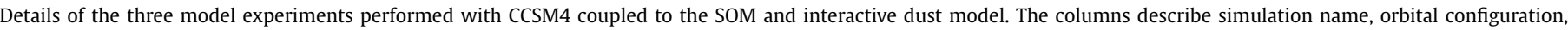
greenhouse gas concentrations (GHC), prescribed vegetation, and soil erodibility map used to scale dust emissions.

\begin{tabular}{|c|c|c|c|c|}
\hline Simulation & Orbital & GHG & Vegetation & Soil erodibility \\
\hline 6 ka Mid-Holocene & $6 \mathrm{ka}$ & $6 \mathrm{ka}$ & PI & $6 \mathrm{ka}$ \\
\hline 6 ka + greening Early Holocene & $6 \mathrm{ka}$ & $6 \mathrm{ka}$ & $\begin{array}{l}\text { Modified North Africa/Arabian Peninsula } \\
\left(10^{\circ}-31^{\circ} \mathrm{N}, 20^{\circ} \mathrm{W}-55^{\circ} \mathrm{E}\right)\end{array}$ & $\begin{array}{l}6 \text { ka with modified North Africa/Arabian } \\
\text { Peninsula }\left(10^{\circ}-31^{\circ} \mathrm{N}, 20^{\circ} \mathrm{W}-55^{\circ} \mathrm{E}\right)\end{array}$ \\
\hline
\end{tabular}

with $\mathrm{LiBO}_{2}$ alkali flux in a high-purity graphite crucible at $1170^{\circ} \mathrm{C}$ for $12 \mathrm{~min}$ to ensure complete dissolution of refractory minerals (Pourmand et al., 2012; Pourmand and Dauphas, 2010). Strontium, Nd, Hf and the REEs ( $\mathrm{La}-\mathrm{Lu}$ ) were separated from the matrix through a three-stage extraction chromatography scheme previously developed for aerosol analysis (Pourmand et al., 2014). Measurements were conducted on a ThermoFisher Scientific Neptune Plus multi-collector inductively coupled plasma mass spectrometer at the Neptune Isotope Lab. The measured ${ }^{143} \mathrm{Nd} /{ }^{144} \mathrm{Nd}$ and ${ }^{176} \mathrm{Hf} /{ }^{177} \mathrm{Hf}$ ratios are reported in " $\varepsilon$ " notation relative to the Chondritic Uniform Reservoir (CHUR) values of $0.512638 \pm 25$ and $0.282785 \pm 11$, respectively (Bouvier et al., 2008). Additional details of the analytical procedure including high-precision isotope measurements for $\mathrm{Sr}-\mathrm{Nd}-\mathrm{Hf}$ systematics and the REEs can be found in (Pourmand et al., 2014).

Model Sm-Nd ages for source rocks were calculated based on assuming ${ }^{143} \mathrm{Nd} /{ }^{144} \mathrm{Nd}=0.51315$ for depleted mantle and a simple evolution leading to modern ${ }^{147} \mathrm{Sm} /{ }^{144} \mathrm{Nd}=0.2137$ (Goldstein et al., 1984; Grousset et al., 1988). As a result, relative changes in model ages are more meaningful than the absolute ages.

$$
\begin{aligned}
& T_{\text {CHUR }}=\frac{1}{\lambda} \\
& * \ln \left[\frac{\left({ }^{143} \mathrm{Nd} /{ }^{144} \mathrm{Nd}\right)_{\text {Sample, today }}-\left({ }^{143} \mathrm{Nd} /{ }^{144} \mathrm{Nd}\right)_{\text {CHUR, today }}}{\left({ }^{147} \mathrm{Sm} /{ }^{144} \mathrm{Nd}\right)_{\text {Sample, today }}-\left({ }^{147} \mathrm{Sm} /{ }^{144} \mathrm{Nd}\right)_{\text {CHUR, today }}}+1\right]
\end{aligned}
$$

where the $T_{\text {CHUR }}$ is the model Sm-Nd age and $\lambda$ is the decay constant $\left(6.25 \times 10^{-12} \mathrm{yr}^{-1}\right)$.

\subsection{Grain-size analysis}

A total of 23 samples were taken from high and low dust intervals along the core and dried overnight at $105^{\circ} \mathrm{C}$. The organic component was oxidized using a solution of $30 \%$ hydrogen peroxide $\left(\mathrm{H}_{2} \mathrm{O}_{2}\right)$ at $200^{\circ} \mathrm{C}$. The remaining fraction was then resuspended in a $0.3 \%$ Hexametaphosphate solution and sub-sampled under stirring. The grain-size distribution was measured using a Beckman Coulter LS 13320 laser granulometer with a range of 0.04 to $2000 \mu \mathrm{m}$ at Aix-Marseille Université, Centre de Recherche et d'Enseignement de Géosciences de l'Environnement (CEREGE, France).

The particle size calculation model was performed in accordance with the Fraunhöfer and Mie theory, in which water was used as the medium (Refractive Index $=1.33$ at $20^{\circ} \mathrm{C}$ ). A refractive index in the range of kaolinite was utilized for the solid phase $(R I=1.56)$ along with absorption coefficients of 0.15 for the $780-\mathrm{nm}$ laser wavelength, and 0.2 for the polarized wavelengths (Buurman et al., 1996). Sample size reproducibility based on independent replicate measurements of the same sample did not exceed 2\% (Psomiadis et al., 2014). Additionally, measurements of the SRM 1003C NIST standard, certified at a D50 of $32.1 \pm 1 \mu \mathrm{m}$ based on SEM analysis, returned a D50 of $31.99 \mu \mathrm{m}$, which is within the analytical uncertainty.

\subsection{HYSPLIT back-trajectory climate simulations}

Three-day air mass back-trajectory ensemble plots at 1000-5000 m starting altitudes were computed for representative winter, spring and summer days using the on-line web version of the HYSPLIT model (Stein et al., 2016). These windows were chosen to approximately correspond with periods of dust sampling at Abadan and Sar Pol Zahab meteorological stations, as well as times of minimum precipitation during winter and summer seasons at Neor Lake (Sharifi et al., 2015). The starting altitude range for the HYSPLIT model was chosen at $1000-5000 \mathrm{~m}$ to provide maximum coverage for the aerosol bearing air masses that reach Neor Lake, which is located at an average altitude of 2500 m.a.s.l. We used the Global Data Assimilation System (GDAS) to provide a comprehensive meteorological dataset for the HYSPLIT models. The GDAS incorporates diverse instrumental data (e.g., surface observations, balloon data, wind profiler data, radar observations, etc.) into gridded, 3-D model space.

\subsection{Climate simulations}

Here we describe the simulations analyzed and performed using two versions of the National Center for Atmospheric Research (NCAR) Community Climate System Model (CCSM). We analyzed the Transient Climate Evolution of the last $21 \mathrm{ka}$ (TraCE), which used CCSM version 3 (CCSM3) (He et al., 2013; Liu et al., 2009). Trace was forced with time-varying changes in orbital parameters, greenhouse gases, ice-sheet orography and extent, solar forcing, freshwater forcing, and interactive vegetation dynamics. We use this simulation to examine how the large-scale circulation varies through time in response to these changing conditions. However, aerosols were prescribed at pre-industrial (PI) conditions and held constant in time.

To examine the role of the greening of North Africa on dust emissions we perform three time slice experiments using CCSM version 4 (CCSM4; Gent et al., 2011) coupled to a slab ocean model (SOM) and interactive dust aerosol model (Albani et al., 2014) (Table 1). The CCSM4 consists of atmosphere, ocean, land, and sea ice components that are linked through a coupler that exchanges state information and fluxes between the components. The atmospheric model is the Community Atmosphere Model version 4 (CAM4), which uses the Lin-Rood finite volume core with a $1.25^{\circ} \times 0.9^{\circ}$ uniform resolution, and 26 levels in the vertical. The land model is the Community Land Model version 4 (CLM4) (Lawrence et al., 2011), which uses the same horizontal resolution as CAM4. In SOM, ocean heat transport convergence is prescribed as a Q-flux, which maintains the climatological sea surface temperatures based on the fully coupled version of CCSM4 (with the dynamic ocean model) (Bitz et al., 2012). Q-flux is calculated using output from the last $20 \mathrm{yr}$ of the $1300 \mathrm{yr}$-long fully coupled mid-Holocene (6 ka) simulation and is used in all our SOM experiments performed here. This is done so that we can focus on the atmospheric changes associated with the surface boundary conditions, though it has been argued that ocean dynamics can provide a modest positive feedback to changes over Africa (Braconnot et al., 2007; Kutzbach and Liu, 1997). We initialized our SOM experiments from their equilibrated $6 \mathrm{ka}$ (Otto-Bliesner et al., 2009) and Preindustrial (1850 A.D., PI) fully coupled climate model simulations that were performed for the Paleoclimate Modeling Intercomparison Project phase 3 (PMIP3) and Coupled Modeling Intercomparison Project phase 5 (CMIP5), respectively, and integrated for $50 \mathrm{yr}$, which is sufficient for the slab model to reach equilibrium. The last $20 \mathrm{yr}$ 
of each slab model simulation is used to calculate the seasonal and annual means. Summer means are based on the climatological June-July-August (JJA) average and spring means are based on the climatological March-April-May (MAM) average.

The interactive dust model includes an active emission scheme, dust transport, and wet and dry deposition processes. Dust emission is a function of wind speed, vegetation and snow cover, soil moisture, and soil erodibility. Soil erodibility accounts for differences in soils' susceptibility to erosion, and is applied as a spatially varying scale factor for dust emissions, which were constrained by particle size-resolved dust mass accumulation rates data and provenance fingerprinting for the $6 \mathrm{ka}$ and PI (see Albani et al., $2015,2014)$. Consequently, dust source regions in the PI experiment are different from the mid-Holocene experiments.

We perform two model simulations of the mid-Holocene: $6 \mathrm{ka}$ and $6 \mathrm{ka}+$ greening. These experiments have the same continental configuration, ice sheets, and topography as the PI experiment, however, greenhouse gases and orbital forcing follow the PMIP3 protocol, and dust source regions differ. Our 6 ka experiment uses the same vegetation cover as the PI experiment. To take into account the "greening" of North Africa in the early Holocene we perform an additional simulation (6 $\mathrm{ka}+$ greening) where we use the same 6 ka orbital forcing, but modify the PI vegetation cover to include the early Holocene North African lake and wetland distribution based on Hoelzmann et al. (1998), and account for the conversion of desert to savanna biomes by replacing bare ground over the North Africa and the Arabian Peninsula $\left(10^{\circ} \mathrm{N}-31^{\circ} \mathrm{N}, 20^{\circ} \mathrm{W}-55^{\circ} \mathrm{E}\right)$ with $70 \%$ C3 grasses, $10 \%$ broadleaf deciduous tropical tree, and $20 \%$ broadleaf deciduous temperate shrub (Castañeda et al., 2009; Jolly et al., 1998). We removed the dust sources by setting the soil erodibility to zero where we modified the vegetation. In CLM4, the soil color is spatially fixed and derived based on the current vegetation distribution. The albedo effect has been shown to increase the precipitation-vegetation feedback (Levis et al., 2004) and alter the sign of the dust-climate feedback (Tegen and Lacis, 1996). Since we replaced the bright Saharan desert with darker savanna, we darkened the soil color in a spatially uniform way, by setting it to values similar to the nearby Sahel. To facilitate comparisons with previous mid-Holocene climate simulations performed for PMIP3, we use $6 \mathrm{ka}$ orbital conditions in all simulations presented here. Although our $6 \mathrm{ka}+$ greening is meant to represent conditions in the early rather than the mid-Holocene ( $6 \mathrm{ka}$ ), additional simulations using $9 \mathrm{ka}$ orbital conditions are needed.

\section{Results and discussion}

\subsection{Geochemical fingerprinting of paleo-dust from West Asia}

A multi-proxy, high-resolution (decadal-centennial) reconstruction of changes in aeolian input and paleoenvironmental conditions at Neor Lake (Fig. 2a and c) has shown that dust fluxes were elevated prior to the onset of the Holocene, dropped significantly and abruptly during the early Holocene (EH, 11,700-6,000 yr BP) but increased again during mid-late Holocene (M-LH, 6,000-present) (Sharifi et al., 2015). In a recent study, Kylander et al. (2016) demonstrated that calculation of the net dust deposition in peat can vary based on the choice of a particular element. While this can potentially influence the absolute flux calculations, the relative changes in dust deposition measured from the input of a specific element (Ti) remains unaffected throughout the record (Sharifi et al., 2015).

We interpreted variations in hydrogen isotopic composition $(\delta \mathrm{D})$ of $\mathrm{C}_{28} n$-alkanoic acid (Fig. 2e), total organic content (TOC), bulk stable isotope composition of organic carbon $\left(\delta^{13} \mathrm{C}_{\mathrm{TOC}}\right)$, $n$-alkane enrichment ratios $\left(\mathrm{P}_{\mathrm{aq}}\right)$, to indicate the early Holocene (EH) was wet in West Asia, consistent with records from Iran
(Mehterian et al., 2017), Africa (Berke et al., 2012; Costa et al., 2014; Tierney et al., 2008) and the eastern Mediterranean (Rossignol-Strick, 1999, 1995) region. In contrast, the M-LH was drier and punctuated by at least eight abrupt episodes of elevated dust fluxes, several of which impacted early human civilizations from the Mesopotamia (Sharifi et al., 2015) and coincide with the ending of the African Humid Period (deMenocal et al., 2000; Gasse, 2000).

In addition to changes in dust fluxes, the elemental composition of paleo-dust from Neor peat suggested that the sources of dust likely changed throughout the record (Sharifi et al., 2015). The mean grain size values of dust measured on the lithogenic fraction of 23 samples (an average resolution of $\sim 600 \mathrm{yr}$ per sample), ranged from 3.3 to $7.4 \mu \mathrm{m}$ throughout the record. The smallest and largest particle sizes measured in all samples ranged from $<0.1 \mu \mathrm{m}$ to $11.4 \mu \mathrm{m}$ (Table SI-1). We should note that, on average, 86.7 volume \% of particles measured in all samples fall below $10 \mu \mathrm{m}$ with only 13.3 volume \% exceeding this threshold (Table SI-1, Fig. SI-1a). The origin of this bimodal distribution (Fig. SI-1b) remains unresolved and we speculate that it may be attributed to contribution from proximal sources, considering the pattern persists throughout the record. These measurements suggest that in spite of significant centennial-millennial scale changes in dust fluxes since the last deglaciation, most part of the dust deposited at Neor Lake was likely transported from range sources (Fig. 2d).

We analyzed 41 dust samples in this record with an average resolution of $\sim 320 \mathrm{yr}$ per sample for radiogenic $\mathrm{Sr}\left({ }^{87} \mathrm{Sr} /{ }^{86} \mathrm{Sr}\right)$, $\mathrm{Nd}\left({ }^{143} \mathrm{Nd} /{ }^{144} \mathrm{Nd}\right)$, Hf $\left({ }^{176} \mathrm{Hf} /{ }^{177} \mathrm{Hf}\right)$ isotopic composition and REE anomalies $\left(\mathrm{La}_{\mathrm{N}} / \mathrm{Lu}_{\mathrm{N}}\right.$, normalized to Post Archaean Australian Shale; Pourmand et al., 2012). These isotope systematics paired with the REE relative abundances and anomalies have proven among the most distinctive geochemical proxies for the source provenance of sediments in modern and ancient deposits (Abouchami et al., 2013; Grousset et al., 1988; Muhs et al., 2014; Pourmand et al., 2014; Scheuvens et al., 2013).

As shown in Fig. $2 \mathrm{f}-\mathrm{g}$ and Table SI-1, the onset of the Holocene is marked by a large shift to distinctly less radiogenic $\varepsilon \mathrm{Nd}$ and $\varepsilon$ Hf values. We also note this abrupt shift that took place within $\sim 300 \mathrm{yr}$ in the geochemical composition of mineral dust was coincident with a large reduction in dust fluxes. The ${ }^{87} \mathrm{Sr} /{ }^{86} \mathrm{Sr}$ isotope ratios become more radiogenic during the same transition from the YD to $\mathrm{EH}$ (Fig. 2i). In general, the $\mathrm{Sr}$ and $\mathrm{Hf}$ isotope ratios show more variability during the entire record and this is likely due to heterogeneity within the source materials and the sensitivity of $\mathrm{Rb}-\mathrm{Sr}$ and Lu-Hf systematics to changes in grain size (Feng et al., 2009). The Sm-Nd model ages (Fig. 2h), which are based on idealized crustal residence ages of the potential source rocks (Goldstein et al., 1984; Grousset et al., 1988) also suggest that contribution from relatively younger sources of aerosols dominated during the EH compared with the YD and M-LH. By 6,000 yr BP, all isotope systematics gradually return to values more akin to pre-Holocene. This transition coincides with a gradual decrease in solar insolation over the northern hemisphere (Fig. 2b).

In order to examine whether the mineral dust in the Neor peat record may have come from local andesitic sources, we analyzed the geochemical signature of several pieces of gravels recovered from the bedrock at the base of the core and a sample from the Sabalan volcanic complex to the west of the study area (Fig. 1). The average isotopic composition of mineral dust from Neor during the last deglacial and Mid-late Holocene is close to, albeit distinct from the values measured in the andesitic bedrock and Sabalan volcanic complex (Figs. 3 and 4). Early Holocene Sr-Nd-Hf values, in contrast, are distinctly different in a regime of reduced dust fluxes, indicating the possibility that early Holocene mineral dust originated from sources with geochemical signatures different from local sources. 


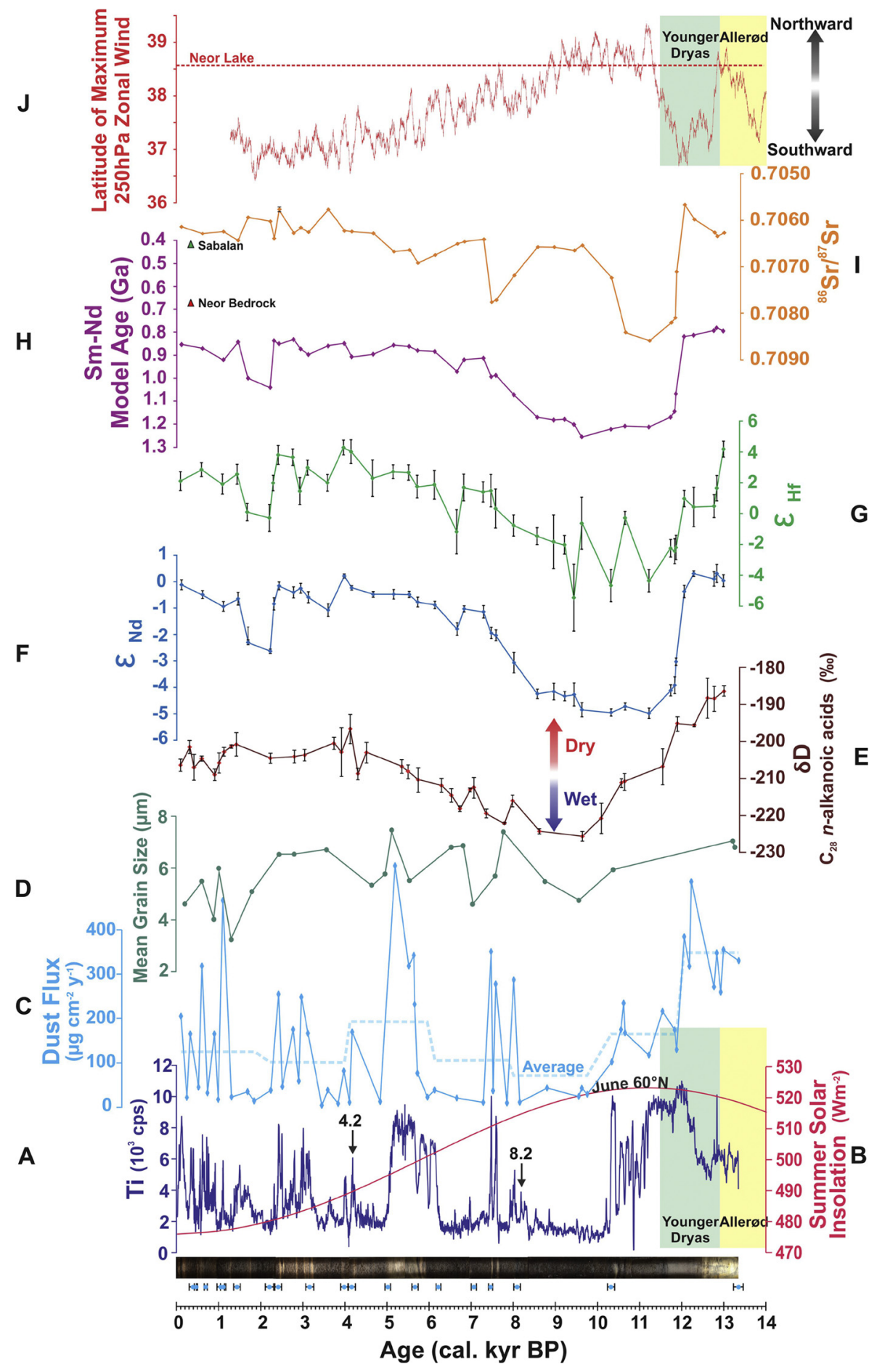

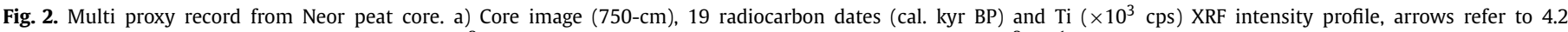

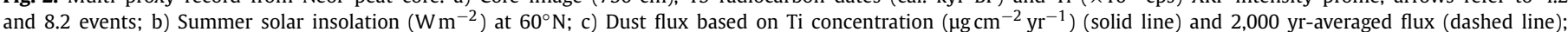

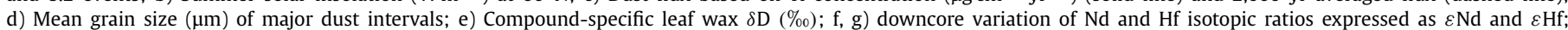

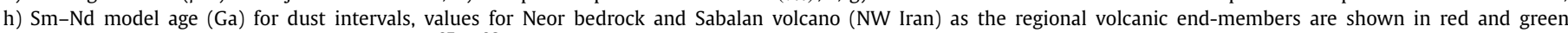

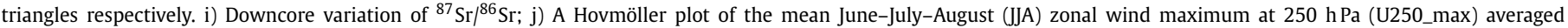

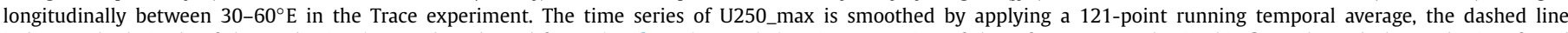

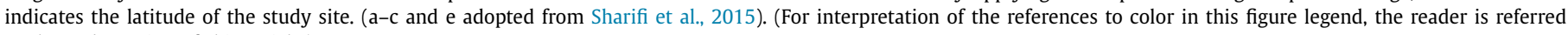
to the web version of this article.)

It can be argued that the geochemical transitions observed in Fig. 2 between the $\mathrm{EH}$ and M-late Holocene occurred due to higher soil coverage over the volcanic complex (i.e., proximal sources) during the early Holocene that led to lower dust fluxes and less contribution from these sources. Indeed, the $\mathrm{Sr}-$ $\mathrm{Nd}-\mathrm{Hf}$ isotopes measured in modern dust samples from West
Asian sources (Figs. 3-4) are closer to values observed during the early Holocene period than the rest of the record, indicating that sources in West Asia may have contributed to deposition of mineral dust to this site during this time. This argument, however, is compounded by the observation that the geochemical composition of mineral dust at Neor has remained relatively 


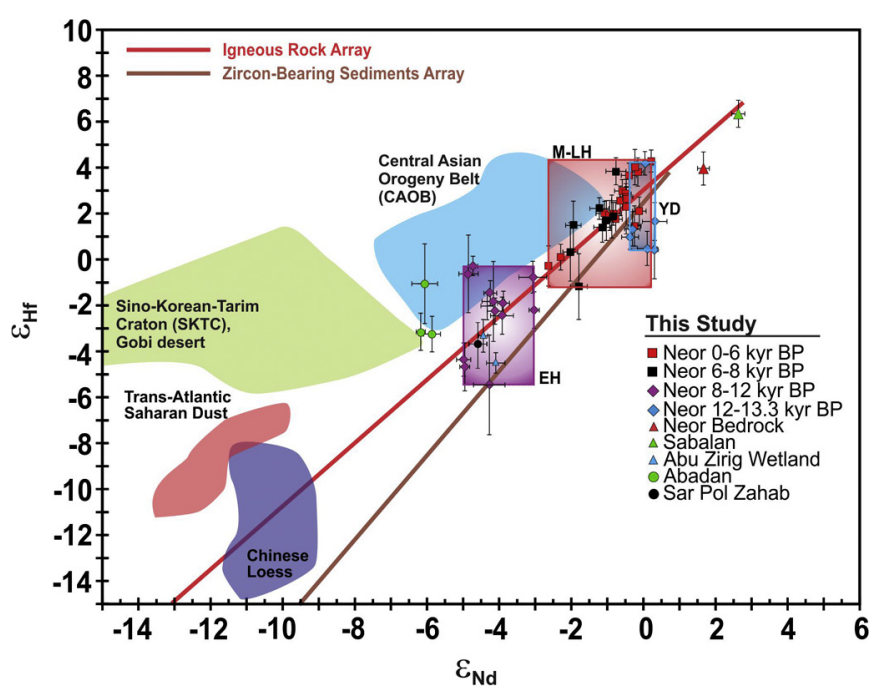

Fig. 3. Radiogenic Hf and Nd isotopes in aerosols from Neor compared to African and Asian source regions. Colored boxed represent clusters of Neor paleo-dust samples for the Younger Dryas (YD), early Holocene (EH) and mid-late Holocene (M-LH). Colored lines denote sediment, and igneous arrays (Bayon et al., 2009). Areas in red, purple, blue and green represent data for Trans-Atlantic Saharan Dust (Pourmand et al., 2014), Chinese Loess (Chen and Li, 2013), Central Asian Orogeny Belt (SAOB) and Sino-Korean-Tarim Craton (SKTC)/Gobi Desert source regions (Zhao et al., 2014) respectively. Uncertainties from this study are 95\% confidence interval. (For interpretation of the references to color in this figure legend, the reader is referred to the web version of this article.)

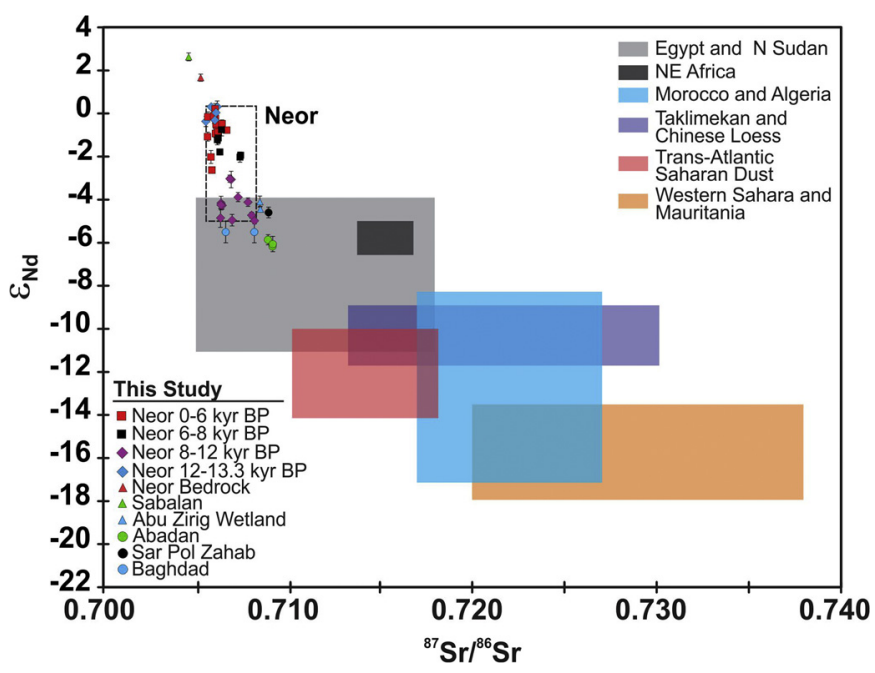

Fig. 4. Radiogenic $\mathrm{Sr}$ and $\mathrm{Nd}$ isotopes in aerosols from Neor compare to the world's source regions. Colored boxes represent ranges of values measured in surfacial samples of North Africa and East Asia (Abouchami et al., 2013; Chen et al., 2007; Chen and Li, 2013; Scheuvens et al., 2013). Dashed box denotes the Neor paleo-dust samples. Uncertainties from this study are 95\% confidence interval. (For interpretation of the references to color in this figure legend, the reader is referred to the web version of this article.)

constant from mid Holocene to modern times, even though the export of West Asian sources of mineral dust to the interior of the Middle East presumably emerged as the region got drier and dustier (Sharifi et al., 2015). Modern satellite observations show our study area receives significant amounts of dust from these western and southwestern sources (Goudie and Middleton, 2006; Prospero et al., 2002), indicating that long-range dust transport from West Asian potential sources must have played an important role throughout mid-late Holocene. The observation that mean particle size of mineral dust measured in Neor peat samples (Fig. 2d, Table SI- 1 and Fig. SI-1a-b) remained below $8 \mu \mathrm{m}$ throughout the record, irrespective of dust flux and changing geochemical com- position, lends strong support to the long range nature of eolian deposition at this location.

\subsection{Dominant regimes of dust emission and transport}

The circulation regime over the study area during $\mathrm{NH}$ summers is dominated by a gradient established between a highpressure system over the Arabian Peninsula and the Iranian Plateau and a low pressure system over higher latitudes of Eurasia. This gradient drives low-level, north-northwesterly winds along the Persian Gulf and over the Arabian Peninsula towards the northern Indian Ocean. During the summer months, the upper level NHSWJ that extends across the entire continent is at its northernmost position (Schiemann et al., 2009). In contrast, the jet is displaced to lower latitudes with sustained westerly directions (Fig. 1) and penetrates eastward from the North Atlantic and across the Mediterranean during winter months. Today, dust storm activities are elevated during spring and summer months across West Asia (Goudie and Middleton, 2006; Kutiel and Furman, 2003; Prospero et al., 2002). Although the origin of most dust storms in the region is from within West Asia, occasional winter and spring outbreaks from NE Africa have also been observed (Goudie and Middleton, 2006; Littmann, 1991) (Figs. 5 and 6). Total Ozone Mapping Spectrometry (TOMS) of atmospheric dust content and Moderate Resolution Imaging Spectroradiometer Deep Blue Level 2 of dust optical depth (M-DB2 DOD) shows areas between the TigrisEuphrates basin and the Arabian Peninsula as the main sources of modern dust to the interior of West Asia (Ginoux et al., 2012; Prospero et al., 2002).

While it is clear that a change in the geochemical composition of paleo-dust occurred throughout the YD and the Holocene at our study area, linking the aerosols to specific sources is challenging. A comparison between the $\mathrm{Sr}-\mathrm{Nd}-\mathrm{Hf}$ isotope composition of paleo-dust from Neor and the available data from sources in $\mathrm{N}$. Africa and deserts in Mongolia and China (Abouchami et al., 2013; Chen et al., 2007; Chen and Li, 2013; Scheuvens et al., 2013) render these areas as unlikely sources (Fig. 4). Some overlap is observed between $\mathrm{Sr}-\mathrm{Nd}$ isotopic composition of the EH samples and sources in Egypt and Sudan. Nevertheless, the geochemical compositions of potential sources in North Africa are far from being fully constrained (Scheuvens et al., 2013).

A marginal overlap is observed between some of the $\varepsilon \mathrm{Nd}-\varepsilon \mathrm{Hf}$ values from Neor and those of clay-sized particles $(<2.0 \mu \mathrm{m})$ from Central Asian Orogeny Belt in China (Zhao et al., 2014) (Fig. 3). However, approximately $3,700 \mathrm{~km}$ longitudinal distance and the general West-East trend of the NHSWJ make significant contribution from these distant eastern sources to West Asia unlikely. Nevertheless, the potential for circumpolar, long-range transport of clay-size particles from the Chinese and Mongolian deserts during the early Holocene when dust fluxes were low cannot be ruled out, considering evidence for transport of these particles has been found in the Greenland ice records (Biscaye et al., 1997).

Aerosol and soil samples collected over SW Iran and soil samples from the Abu Zirig wetland in Iraq analyzed in this study plot close to ${ }^{87} \mathrm{Sr} /{ }^{86} \mathrm{Sr}-\varepsilon \mathrm{Nd}$ values of the $\mathrm{EH}$ samples (Fig. 1 and 4 ). A dust sample from Sar Pol Zahab, located $470 \mathrm{~km}$ southwest of Neor, (Figs. 1 and 6) also falls within the cluster of samples from the $\mathrm{EH}$ with respect to $\varepsilon \mathrm{Nd}-\varepsilon \mathrm{Hf}$ composition (Fig. 3). In contrast, the fractionation of light/heavy REE $\left(\mathrm{La}_{N} / \mathrm{Lu}_{\mathrm{N}}\right)$ as a function of SmNd model ages (Fig. 7) set modern samples distinctly apart from the paleo-dust. Although we now have a relatively high resolution record of dust composition over the Holocene from Neor Lake, the paucity of information on the geochemical and mineralogical composition of potential sources of mineral dust in West Asia make it difficult to establish a definitive linkage between sources and the receptor site(s). 

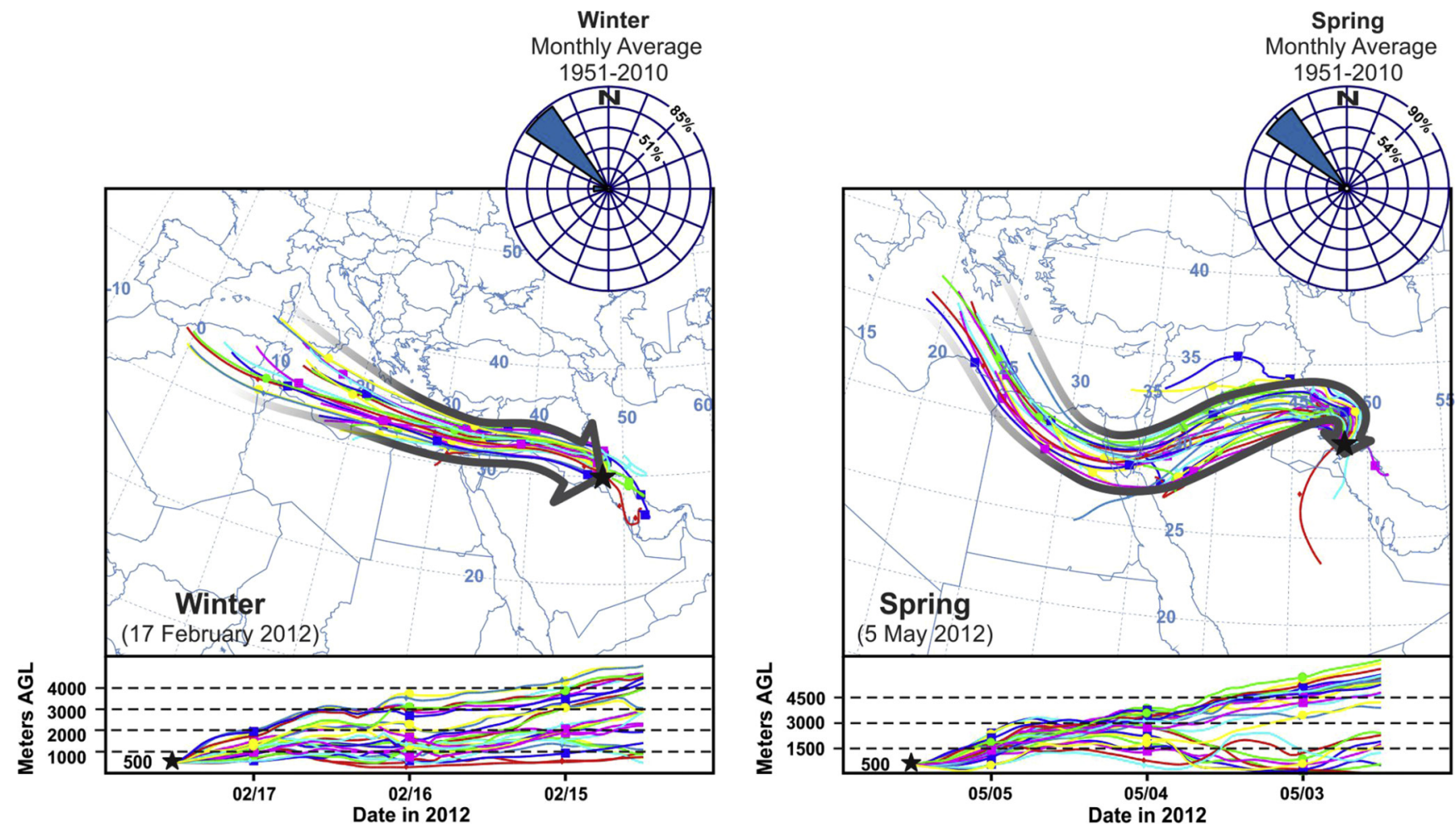

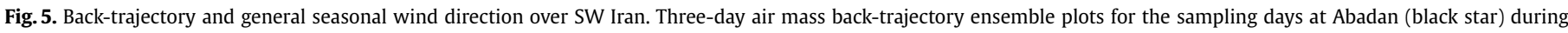

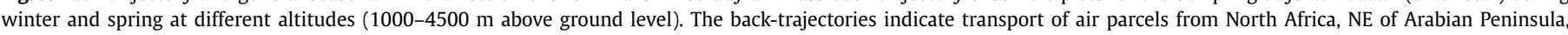

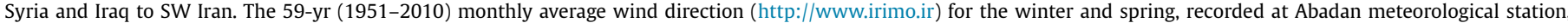
indicates the northwesterly dominant wind regime.

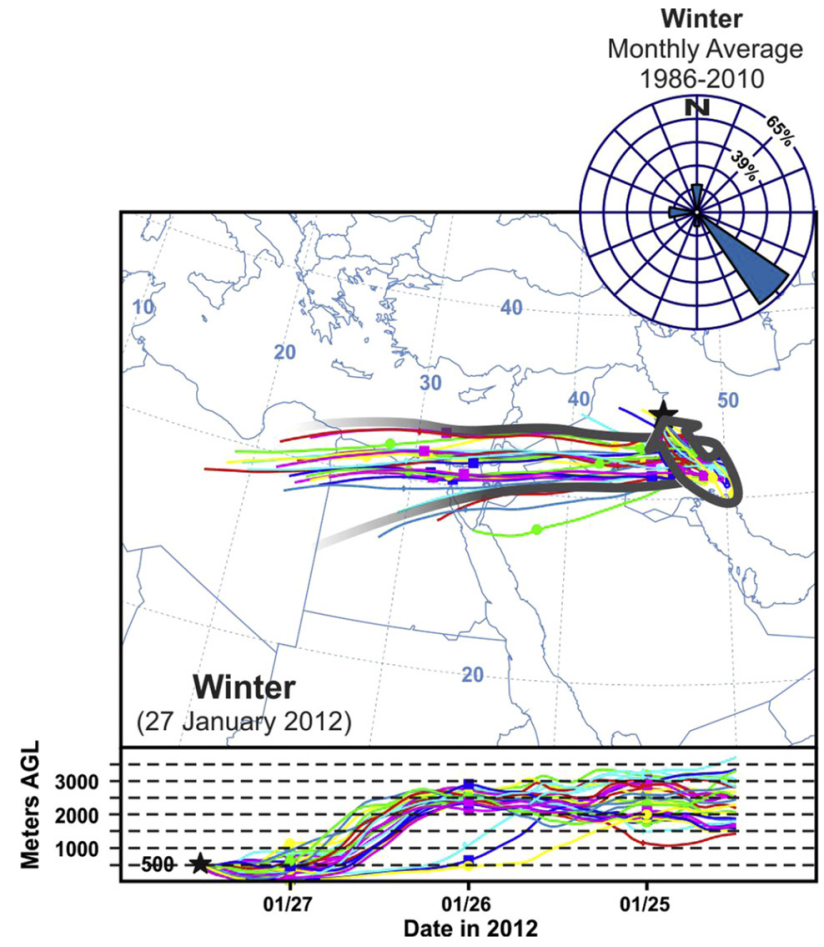

Fig. 6. Back-trajectory and general seasonal wind direction over W Iran. Three-day air mass back-trajectory ensemble plots for the sampling days at Sar Pol Zahab (black star) during winter at various altitudes (500-4500 m above ground level). Based on this back-trajectory, air parcel passes over Jordan, NE of Arabian Peninsula and Iraq through a westerly wind and reaches to Sar Pol Zahab in W Iran via a southwesterly wind. Furthermore, the 24-yr (1986-2010) monthly average wind direction (http://www.irimo.ir) for the winter, recorded at Sar Pol Zahab meteorological station, is in good agreement with the model output and indicates that the southeasterly winds are dominant during the winter season.

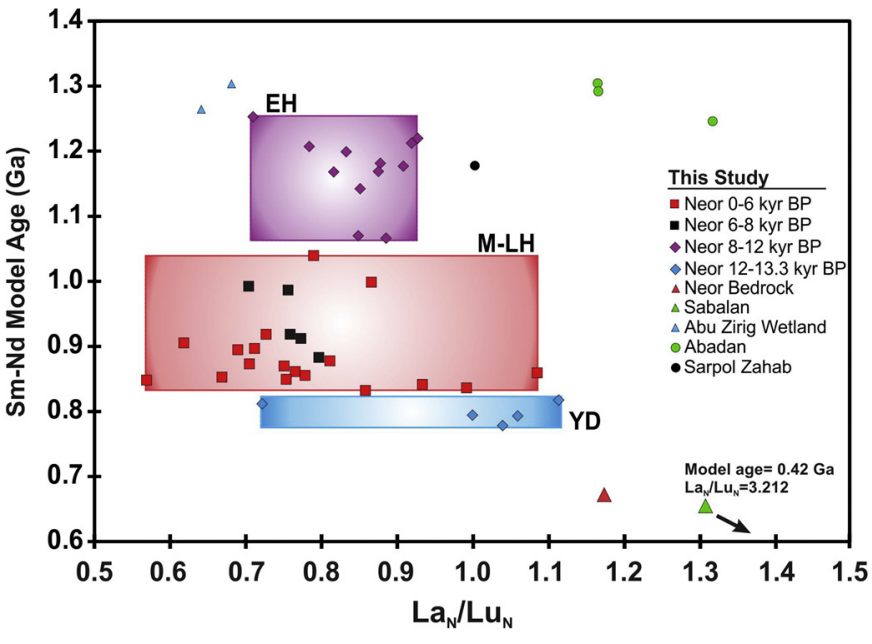

Fig. 7. Difference in Sm-Nd model ages compare to normalized $\mathrm{La}_{\mathrm{N}} / \mathrm{Lu}_{\mathrm{N}}$ ratios. Colored boxed represent clusters of Neor paleo-dust samples for the Younger Dryas (YD), the early Holocene (EH) and the mid-late Holocene (M-LH). Colors and symbols are same as in Fig. 3. (For interpretation of the references to color in this figure legend, the reader is referred to the web version of this article.)

\subsection{Simulations of atmospheric circulation and dust emission and deposition}

To help interpret the observed changes in the geochemical composition of paleo-dust from Neor peat, we analyzed changes in atmospheric circulation and dust emission rates in a transient climate model simulation that covers the last 21,000 $\mathrm{yr}$ (TraCE) and in three time slice simulations of the $\mathrm{EH}$ ( $6 \mathrm{ka}+$ greening), $\mathrm{MH}$ (6 ka), and Late Holocene (PI) (Table 1).

Orbital-driven changes in insolation can drive shifts in the NHSWJ and thereby impact atmospheric circulation and large- 

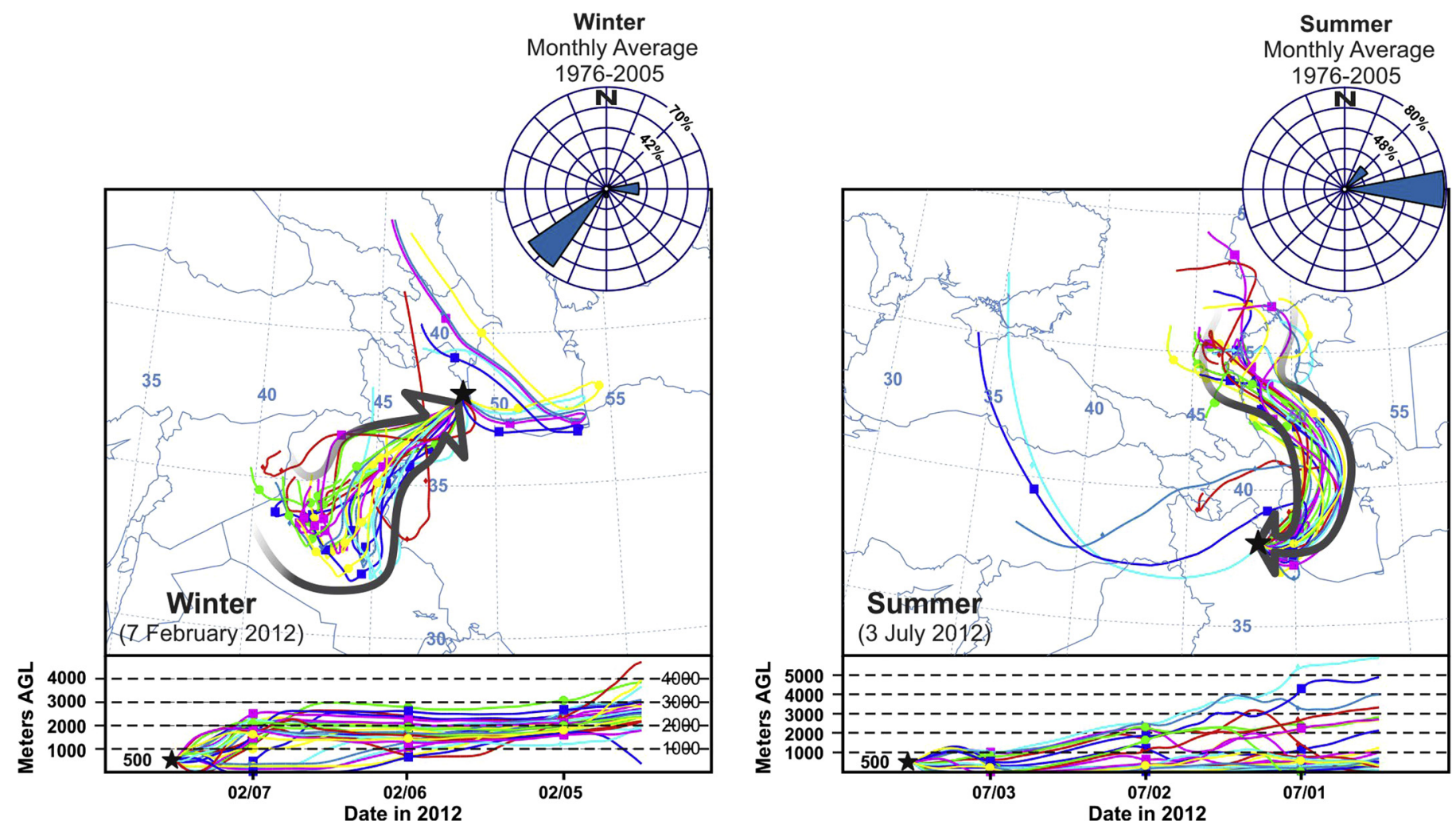

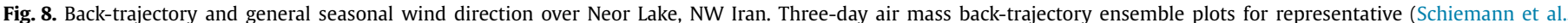

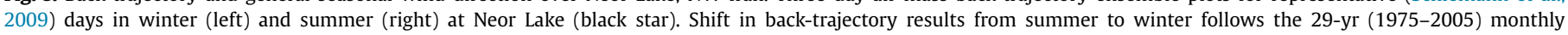
average prevailing wind direction recorded at Ardabil meteorological station (located $50 \mathrm{~km} \mathrm{NE}$ of the Neor Lake), see text for discussion.

scale precipitation patterns over the eastern Mediterranean region (Brayshaw et al., 2010), Tibetan Plateau (Schiemann et al., 2009) and East Asia (Chiang et al., 2015; Nagashima et al., 2011). The position of NHSWJ in the TraCE simulation moved equatorward throughout the Holocene, and followed the $\mathrm{NH}$ June insolation curve (Fig. $2 \mathrm{~b}$ and $\mathrm{j}$ ). Analysis of the maximum in zonal wind at 250-hPa averaged over June-July-August (JJA) indicates a clear poleward (equatorward) shift in the NHSWJ when boreal summer insolation was high (low). Additionally, the YD cold period shows a significant equatorward shift in the JJA NHSWJ, whereas the Bølling-Allerød warm interval indicates a poleward shift in the jet (Fig. 2j). These results highlight the importance of orbital forcing and the Northern Hemisphere temperature on the $\mathrm{NH}$ mid-latitude circulation.

The location and high elevation of Neor Lake makes it ideal to record the migration in the NHSWJ from a northernmost position of $\sim 39^{\circ} \mathrm{N}$ in the $\mathrm{EH}$ to a southernmost position of $\sim 37^{\circ} \mathrm{N}$ in the LH. Previous studies have shown how the migration of the main axis of the NHSWJ from higher latitudes during the summer to lower latitudes in winter modulates air mass circulation and precipitation patterns over West Asia and the Tibetan Plateau (Nagashima et al., 2011; Schiemann et al., 2009). Three-day HYSPLIT back-trajectory ensembles for selected days (Schiemann et al., 2009) during winter (M-LH analog) and summer (EH analog) over Neor Lake indicate a distinct shift in the direction of air masses due to changes in the position and intensity of the NHSWJ (Fig. 8). The shift from N-NW sources in the summer to western sources of air masses during winter months is also supported by records of wind direction (29-yr monthly average, 1976-2005) from the nearest meteorological station located $50 \mathrm{~km} \mathrm{NE}$ of our study area (Fig. 8). Together, these results suggest that contributions from the Mesopotamian source regions in Iraq, Syria and the Arabian Peninsula to atmospheric dust deposition over the Neor Lake are higher during the winter, whereas contributions from
Central Asian sources such as Qobustan in Azerbaijan, Atrek delta of Turkmenistan, Turan plain of Uzbekistan, and the region around the Aral Sea (Fig. 1) become more pronounced during the summer.

This observation is further supported in our equilibrium climate model simulations. The differences in dust emissions between our $6 \mathrm{ka}$ and PI simulations are attributed both to differences in climate (due to orbital changes and greenhouse gas forcing), as well as differences in dust source regions (i.e., soil erodibility). Since all boundary conditions are the same in our $6 \mathrm{ka}$ and $6 \mathrm{ka}+$ greening experiments, except for the land surface characteristics of North Africa and the Arabian Peninsula, changes in dust emissions are due solely to changes in climate driven by the greening. There is a large reduction in the annual mean atmospheric dust loading over North Africa at 6 ka compared to the PI and in the $6 \mathrm{ka}+$ greening experiment compared to the 6 ka (Fig. 9). Consistent with the proxy data from Neor Lake, which shows a reduction in dust fluxes at Neor Lake in the early to mid-Holocene compared to the late Holocene, we also find a decrease in annual mean dust deposition in our $6 \mathrm{ka}+$ greening and $6 \mathrm{ka}$ experiments (37 and $33 \mathrm{~g} \mathrm{~m}^{-2} \mathrm{yr}^{-1}$, respectively) compared to the PI $\left(40 \mathrm{~g} \mathrm{~m}^{-2} \mathrm{yr}^{-1}\right)$. Compared to the 6 ka simulation, the greening of North Africa and the Arabian Peninsula in the early Holocene (6 ka + greening) results in an a slight increase in the simulated annual mean dust deposition at the study site, that is driven largely by enhanced dust emissions from West and Central Asia in boreal winter (gray box in Fig. 10A). In boreal winter, the greening of North Africa causes a decrease in precipitation minus evaporation over central and Iran (Fig. 10B). This enhances aridity and results in more dust mobilization compared to $6 \mathrm{ka}$ conditions. The anomalous easterly low level winds in the $6 \mathrm{ka}+$ greening experiment exports dust westward towards Neor Lake (Fig. 10A). In boreal summer, the greening of North Africa results in wetter conditions (positive precipitation minus evaporation, Fig. 10D) over central Asia and Iran but dust emissions averaged over this region are similar in 
Annual Dust Aerosol Optical Depth

$6 \mathrm{ka}-\mathrm{PI}$
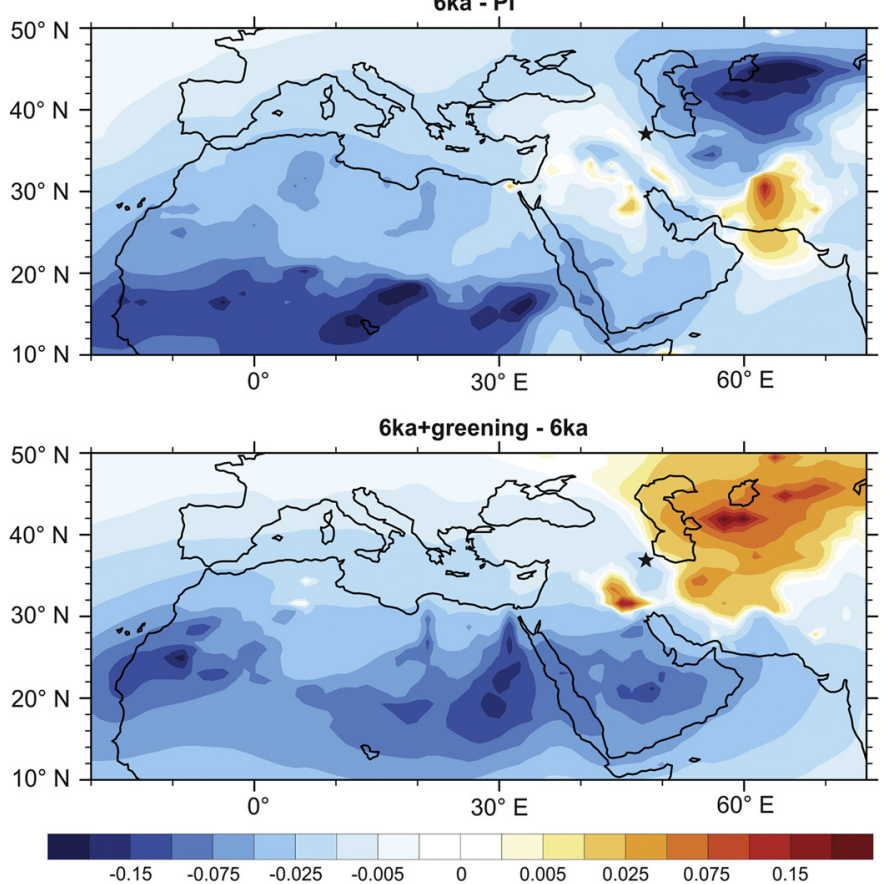

Fig. 9. Annual mean dust aerosol optical depth anomalies. The change in annual mean dust aerosol optical depth in our 6 ka simulation compared to our PI simulation (top) and our $6 \mathrm{ka}+$ greening simulation compared to the 6 ka simulation (bottom). Our simulations show a reduction in the annual mean atmospheric dust loading over North Africa and the Arabian Peninsula and at the Neor location. Black star denotes the location of the study site. (For interpretation of the references to color bar in this figure, the reader is referred to the web version of this article.)
$6 k a+g r e e n i n g-6 k a$

both the $6 \mathrm{ka}+$ greening and 6 ka simulations. We hypothesize that the greening of North Africa resulted in greater drying over Central Asia in boreal winter and resulted in these regions dominating dust export to Neor Lake during the African Humid Period. This is consistent with our new proxy records that show the dust deposited during the African Humid Period had a significantly different isotopic and geochemical signature than the dust deposited in the LH (Fig. $2 \mathrm{f}$ and e, Figs. 3 and 4).

\section{Conclusions and implications}

Geochemical fingerprinting of paleo-dust from Neor Lake peat core with radiogenic $\mathrm{Sr}-\mathrm{Nd}-\mathrm{Hf}$ isotopes and REE anomalies reveal sources of dust were different between the dry Younger Dryas, when dust fluxes were high, and the wet period of the early Holocene when dust fluxes were substantially lower. A poleward shift in the westerly jet axis together with less dust emission from North African sources covered by vegetation hampered the longrange transport of African dust to western Asia during the early Holocene. At this time, transport from Mesopotamian and Central Asian sources of mineral dust may have dominated atmospheric deposition over NW Iran, albeit contributing at lower fluxes than the late Holocene. The composition of paleo-dust gradually became more similar to the Younger Dryas during the middle-late Holocene. Migration of the main axis of the NHSWJ towards the equator during the drier middle-late Holocene allowed the jets to transport higher fluxes of dust from potential source regions in West Asia as well as from the NE African sources. With increased temperatures resulting from global warming, it is expected that the Middle East will become more arid in the next few decades to centuries (IPCC, 2014). This will likely expose new sources of mineral dust available for export from these regions to the interior of West Asia.

\section{DJF Dust Emission $\left(\mathrm{g} \mathrm{m}^{-2} \mathrm{yr}^{-1}\right)$ $6 \mathrm{ka}+$ greening - $6 \mathrm{ka}$}

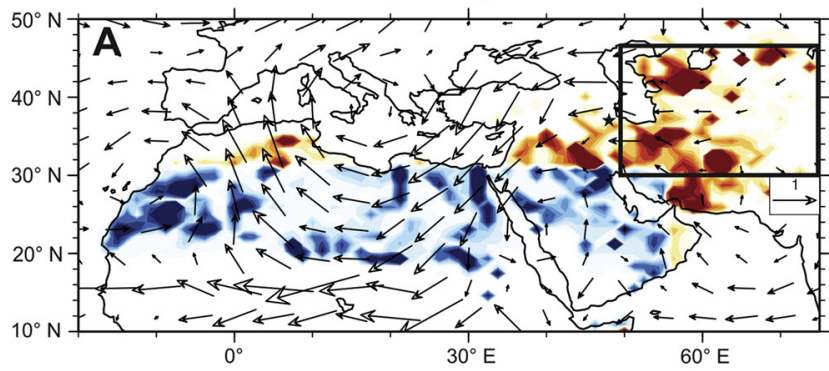

JJA Dust Emission $\left(\mathrm{g} \mathrm{m}^{-2} \mathrm{yr}^{-1}\right)$ $6 \mathrm{ka}+\mathrm{greening}-6 \mathrm{ka}$

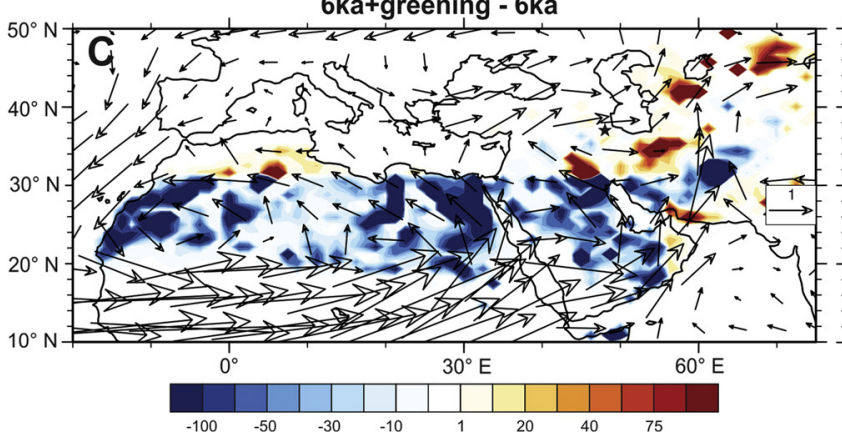

\section{DJF Precipitation-Evaporation (percent change)} $6 \mathrm{ka}+$ greening - $6 \mathrm{ka}$

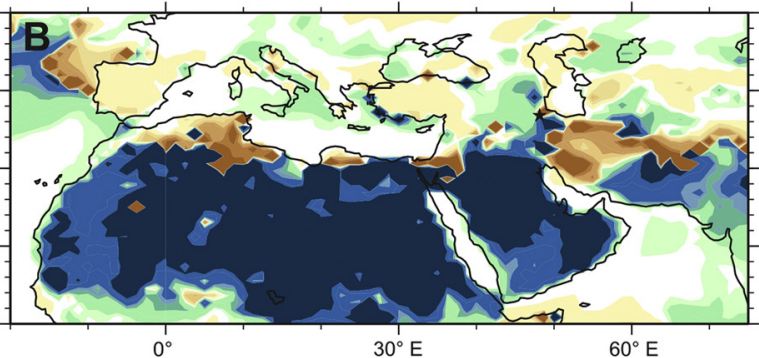

JJA Precipitation-Evaporation (percent change) $6 \mathrm{ka}+$ greening - $6 \mathrm{ka}$

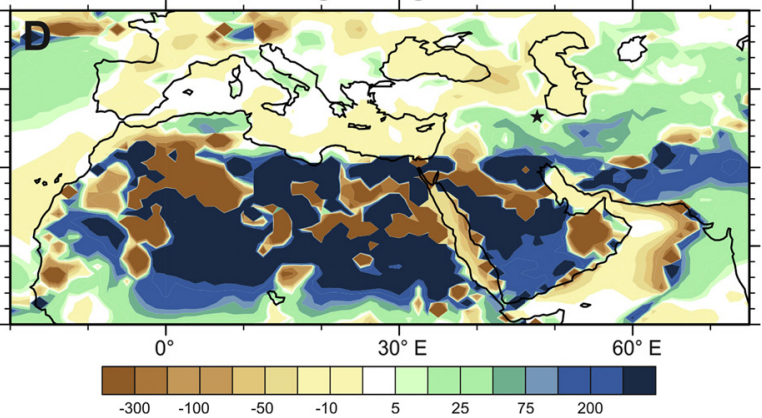

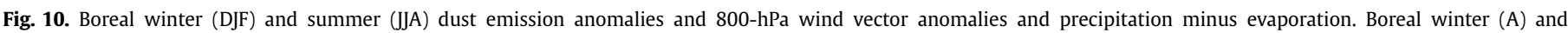

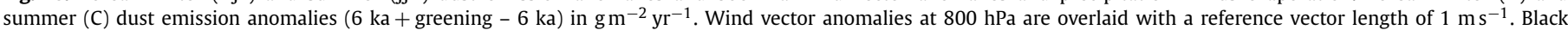

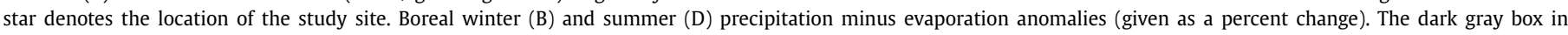

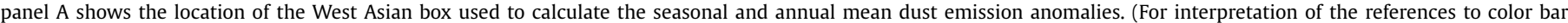
in this figure, the reader is referred to the web version of this article.) 


\section{Acknowledgements}

This research was supported by National Science Foundation grants EAR-1003639 to A. Pourmand, EAR-1003529 to E.A. Canuel, and NSF-1304540 to A.C. Clement and L.N. Murphy. The field campaign was supported by INIOAS project No 391-012-01. The authors would like to acknowledge the high-performance computing support from Yellowstone (ark:/85065/d7wd3xhc) provided by NCAR's Computational and Information Systems Laboratory, sponsored by the National Science Foundation. TraCE-21ka was made possible by the DOE INCITE computing program, and supported by NCAR, the NSF P2C2 program, and the DOE Abrupt Change and EaSM programs. The authors thank Dr. Jamshid Hassanzadeh (California Institute of Technology) and Dr. Ahmed I. Rushdi (King Saud University) for sharing valuable samples from Sabalan Volcano (Iran) and Abu Zirig Wetland (Iraq). We are grateful to Dr. Morteza Djamali for providing support for grain size analysis. We also thank Naser Ghasemi and Asadollah Taheri for their support during the field work. The authors thank the journal Editor Martin Frank and two anonymous reviewers for their feedback and suggestions that significantly improved the original submission.

\section{Appendix A. Supplementary material}

Supplementary material related to this article can be found online at https://doi.org/10.1016/j.epsl.2017.10.001.

\section{References}

Abouchami, W., Näthe, K., Kumar, A., Galer, S.J.G., Jochum, K.P., Williams, E., Horbe, A.M.C., Rosa, J.W.C., Balsam, W., Adams, D., Mezger, K., Andreae, M.O., 2013. Geochemical and isotopic characterization of the bodélé depression dust source and implications for transatlantic dust transport to the Amazon basin. Earth Planet. Sci. Lett. 380, 112-123. http://dx.doi.org/10.1016/j.epsl.2013.08.028.

Aguado, E., Burt, J.E., 2012. Understanding Weather and Climate, 6th ed. Prentice Hall.

Ahmady-Birgani, H., Mirnejad, H., Feiznia, S., McQueen, K.G., 2015. Mineralogy and geochemistry of atmospheric particulates in Western Iran. Atmos. Environ. 119, 262-272. http://dx.doi.org/10.1016/j.atmosenv.2015.08.021.

Albani, S., Mahowald, N.M., Perry, A.T., Scanza, R.A., Heavens, N.G., Zender, C.S. Maggi, V., Kok, J.F., Otto-Bliesner, B.L., 2014. Improved dust representation in the community atmosphere model. J. Adv. Model. Earth Syst. 6, 541-570. http://dx. doi.org/10.1002/2013MS000279.

Albani, S., Mahowald, N.M., Winckler, G., Anderson, R.F., Bradtmiller, L.I., Delmonte, B., François, R., Goman, M., Heavens, N.G., Hesse, P.P., Hovan, S.A., Kang, S.G., Kohfeld, K.E., Lu, H., Maggi, V., Mason, J.A., Mayewski, P.A., McGee, D., Miao, X., Otto-Bliesner, B.L., Perry, A.T., Pourmand, A., Roberts, H.M., Rosenbloom, N., Stevens, T., Sun, J., 2015. Twelve thousand years of dust: the Holocene global dust cycle constrained by natural archives. Clim. Past 11, 869-903. http://dx.doi. org/10.5194/cp-11-869-2015.

Arimoto, R., 2001. Eolian dust and climate: relationships to sources, tropospheric chemistry, transport and deposition. Earth-Sci. Rev. 54, 29-42. http://dx.doi.org/ 10.1016/S0012-8252(01)00040-X.

Bayon, G., Burton, K.W., Soulet, G., Vigier, N., Dennielou, B., Etoubleau, J., Ponzevera E., German, C.R., Nesbitt, R.W., 2009. Hf and Nd isotopes in marine sediments: constraints on global silicate weathering. Earth Planet. Sci. Lett. 277, 318-326. http://dx.doi.org/10.1016/j.epsl.2008.10.028.

Berke, M.A., Johnson, T.C., Werne, J.P., Grice, K., Schouten, S., Sinninghe Damsté, J.S. 2012. Molecular records of climate variability and vegetation response since the Late Pleistocene in the Lake Victoria basin, East Africa. Quat. Sci. Rev. 55, 59-74. http://dx.doi.org/10.1016/j.quascirev.2012.08.014.

Biscaye, P.E., Grousset, F.E., Revel, M., Van der Gaast, S., Zielinski, G.A., Vaars, A., Kukla, G., 1997. Asian provenance of glacial dust (stage 2) in the Greenland Ice Sheet Project 2 Ice Core, Summit, Greenland. J. Geophys. Res. 102, 26765. http://dx.doi.org/10.1029/97JC01249.

Bitz, C.M., Shell, K.M., Gent, P.R., Bailey, D.A., Danabasoglu, G., Armour, K.C., Holland, M.M., Kiehl, J.T., 2012. Climate sensitivity of the community climate system model, version 4. J. Climate 25, 3053-3070. http://dx.doi.org/10.1175/ JCLI-D-11-00290.1.

Bouvier, A., Vervoort, J.D., Patchett, P.J., 2008. The Lu-Hf and Sm-Nd isotopic composition of CHUR: Constraints from unequilibrated chondrites and implication for the bulk composition of terrestrial planets. Earth Planet. Sci. Lett. 273, 48-57. http://dx.doi.org/10.1016/j.epsl.2008.06.010.
Braconnot, P., Otto-Bliesner, B., Harrison, S., Joussaume, S., Peterchmitt, J.-Y., AbeOuchi, A., Crucifix, M., Fichefet, T., Hewitt, C.D., Kageyama, M., Kitoh, A., Loutre, M.-F., Marti, O., Merkel, U., Ramstein, G., Valdes, P., Weber, L., Yu, Y., Zhao, Y., 2007. Results of PMIP2 coupled simulations of the Mid-Holocene and Last Glacial Maximum \&ndash; Part 1: experiments and larg-scale features. Clim. Past 3, 261-277.

Brayshaw, D.J., Hoskins, B., Black, E., 2010. Some physical drivers of changes in the winter storm tracks over the North Atlantic and Mediterranean during the Holocene. Philos. Trans. R. Soc. A, Math. Phys. Eng. Sci. 368, 5185-5223. http://dx.doi.org/10.1098/rsta.2010.0180.

Buurman, P., van Lagen, B., Velthorst, E.J. (Eds.), 1996. Manual for Soil and Water Analysis. Backhuys Publishers, Leiden, The Netherlands.

Castañeda, I.S., Mulitza, S., Schefuss, E., dos Santos, R.A.L., Damste, J.S.S., Schouten, S., 2009. Wet phases in the Sahara/Sahel region and human migration patterns in North Africa. Proc. Natl. Acad. Sci. USA 106, 20159-20163. http://dx.doi. org/10.1073/Pnas.0905771106.

Chen, J., Li, G., Yang, J., Rao, W., Lu, H., Balsam, W., Sun, Y., Ji, J., 2007. Nd and $\mathrm{Sr}$ isotopic characteristics of Chinese deserts: implications for the provenances of Asian dust. Geochim. Cosmochim. Acta 71, 3904-3914. http://dx.doi.org/ 10.1016/j.gca.2007.04.033.

Chen, Z., Li, G., 2013. Evolving sources of eolian detritus on the Chinese Loess Plateau since early Miocene: tectonic and climatic controls. Earth Planet. Sci. Lett. 371-372, 220-225. http://dx.doi.org/10.1016/j.epsl.2013.03.044.

Chiang, J.C.H., Fung, I.Y., Wu, C.H., Cai, Y., Edman, J.P., Liu, Y., Day, J.A., Bhattacharya, T., Mondal, Y., Labrousse, C.A., 2015. Role of seasonal transitions and westerly jets in East Asian paleoclimate. Quat. Sci. Rev. 108, 111-129. http://dx.doi. org/10.1016/j.quascirev.2014.11.009.

Choobari, O.A., Zawar-Reza, P., Sturman, A., 2014. The global distribution of mineral dust and its impacts on the climate system: a review. Atmos. Res. 138, 152-165. http://dx.doi.org/10.1016/j.atmosres.2013.11.007.

Costa, K., Russell, J., Konecky, B., Lamb, H., 2014. Isotopic reconstruction of the African Humid Period and Congo Air Boundary migration at Lake Tana, Ethiopia. Quat. Sci. Rev. 83, 58-67. http://dx.doi.org/10.1016/j.quascirev.2013.10.031.

deMenocal, P., Ortiz, J., Guilderson, T., Adkins, J., Sarnthein, M., Baker, L., Yarusinsky, M., 2000. Abrupt onset and termination of the African Humid Period: rapid climate responses to gradual insolation forcing. Quat. Sci. Rev. 19, 347-361.

Feng, J.L., Zhu, L.P., Zhen, X.L., Hu, Z.G., 2009. Grain size effect on Sr and Nd isotopic compositions in eolian dust. Geochem. J. 43, 123-131.

Gasse, F., 2000. Hydrological changes in the African tropics since the last glacial maximum. Quat. Sci. Rev. 19, 189-211. http://dx.doi.org/10.1016/S02773791(99)00061-X.

Gent, P.R., Danabasoglu, G., Donner, L.J., Holland, M.M., Hunke, E.C., Jayne, S.R., Lawrence, D.M., Neale, R.B., Rasch, P.J., Vertenstein, M., Worley, P.H., Yang, Z.L., Zhang, M., 2011. The community climate system model version 4. J. Climate 24, 4973-4991. http://dx.doi.org/10.1175/2011JCLI4083.1.

Ginoux, P., Prospero, J.M., Gill, T.E., Hsu, N.C., Zhao, M., 2012. Global-scale attribution of anthropogenic and natural dust sources and their emission rates based on modis deep blue aerosol products. Rev. Geophys. 50, 1-36. http://dx.doi.org/10.1029/2012RG000388.

Goldstein, S.L., Onions, R.K., Hamilton, P.J., 1984. A Sm-Nd isotopic study of atmospheric dusts and particulates from major river systems. Earth Planet. Sci. Lett. 70, 221-236. http://dx.doi.org/10.1016/0012-821X(84)90007-4.

Goudie, A.S., Middleton, N.J., 2006. Desert Dust in Global System. Springer, Berlin, Heidelberg, New York.

Grousset, F.E., Biscaye, P.E., Zindler, A., Prospero, J., Chester, R., 1988. Neodymium isotopes as tracers in marine sediments and aerosols, North Atlantic. Earth Planet. Sci. Lett. 87, 367-378. http://dx.doi.org/10.1016/0012-821X(88)90001-5.

Hamidi, M., Kavianpour, M.R., Shao, Y., 2013. Synoptic analysis of dust storms in the Middle East. Asia-Pac. J. Atmos. Sci. 49, 279-286. http://dx.doi.org/10.1007/ s13143-013-0027-9.

He, F., Shakun, J.D., Clark, P.U., Carlson, A.E., Liu, Z., Otto-Bliesner, B.L., Kutzbach, J.E., 2013. Northern Hemisphere forcing of Southern Hemisphere climate during the last deglaciation. Nature 494, 81-85. http://dx.doi.org/10.1038/nature11822.

Hoelzmann, P., Jolly, D., Harrison, S.P., Laarif, F., Bonnefille, R., Pachur, H.J., 1998. MidHolocene land-surface conditions in northern Africa and the Arabian peninsula: a data set for the analysis of biogeophysical feedbacks in the climate system. Glob. Biogeochem. Cycles 12, 35-51. http://dx.doi.org/10.1029/97GB02733.

IPCC, 2014, IPCC Climate Change (2014) Synthesis Report. Contribution of Working Groups I, II and III to the Fifth Assessment Report of the Intergovernmental Panel on Climate Change. Intergovernmental Panel on Climate Change, Geneva, Switzerland, 2014

Jolly, D., Harrison, S., Damnati, B., Bonnefille, R., 1998. Simulated climate and biomes of Africa during the late quaternary. Quat. Sci. Rev. 17, 629-657. http://dx.doi. org/10.1016/S0277-3791(98)00015-8.

Kutiel, H., Furman, H., 2003. Dust Storms in the Middle East: sources of origin and their temporal characteristics. Indoor Built Environ. 12, 419-426. http:// dx.doi.org/10.1177/1420326X03037110.

Kutzbach, J.E., Liu, Z., 1997. Response of the African Monsoon to orbital forcing and ocean feedbacks in the middle Holocene. Science 80 (278), 440-443. http://dx. doi.org/10.1126/science.278.5337.440. 
Kylander, M.E., Martínez-Cortizas, A., Bindler, R., Greenwood, S.L., Mörth, C.M., Rauch, S., 2016. Potentials and problems of building detailed dust records using peat archives: an example from Store Mosse (the "Great Bog"), Sweden. Geochim. Cosmochim. Acta 190, 156-174. http://dx.doi.org/10.1016/ j.gca.2016.06.028.

Lawrence, D.M., Oleson, K.W., Flanner, M.G., Thornton, P.E., Swenson, S.C., Lawrence, P.J., Zeng, X., Yang, Z.-L., Levis, S., Sakaguchi, K., Bonan, G.B., Slater, A.G., 2011. Parameterization improvements and functional and structural advances in Version 4 of the community land model. J. Adv. Model. Earth Syst. 3, 1-27. http://dx.doi.org/10.1029/2011MS000045.

Levis, S., Bonan, G.B., Bonfils, C., 2004. Soil feedback drives the mid-Holocene North African monsoon northward in fully coupled CCSM2 simulations with a dynamic vegetation model. Clim. Dyn. 23, 791-802. http://dx.doi.org/10.1007/ s00382-004-0477-y.

Littmann, T., 1991. Dust storm frequency in Asia: climatic control and variability. Int. J. Climatol. 11, 393-412. http://dx.doi.org/10.1002/joc.3370110405.

Liu, Y., Lo, L., Shi, Z., Wei, K.-Y., Chou, C.-J., Chen, Y.-C., Chuang, C.-K., Wu, C.-C., Mii, H.-S., Peng, Z., Amakawa, H., Burr, G.S., Lee, S.-Y., DeLong, K.L., Elderfield, H., Shen, C.-C., 2015. Obliquity pacing of the western Pacific Intertropical Convergence Zone over the past 282,000 years. Nat. Commun. 6, 10018. http://dx.doi.org/10.1038/ncomms10018.

Liu, Z., Otto-Bliesner, B.L., Brady, E.C., Tomas, R., Clark, P.U., Carlson, A.E., LynchStieglitz, J., Curry, W., Brook, E., Jacob, R., Kutzbach, J., Cheng, J., 2009. Transient simulation of last deglaciation with a new mechanism for Bolling-Allerod warming. Science 80 (325), 310-314

McGee, D., Donohoe, A., Marshall, J., Ferreira, D., 2014. Changes in ITCZ location and cross-equatorial heat transport at the Last Glacial Maximum, Heinrich Stadial 1, and the mid-Holocene. Earth Planet. Sci. Lett. 390, 69-79. http://dx.doi.org/ 10.1016/j.epsl.2013.12.043.

Mehterian, S., Pourmand, A., Sharifi, A., Lahijani, H.A.K., Naderi, M., Swart, P.K., 2017. Speleothem records of glacial/interglacial climate from Iran forewarn of future Water Availability in the interior of the Middle East. Quat. Sci. Rev. 164, 187-198. http://dx.doi.org/10.1016/j.quascirev.2017.03.028.

Middleton, N.J., 1986. A geography of dust storms in South-West Asia. Int. J. Climatol. 6, 183-196. http://dx.doi.org/10.1002/joc.3370060207.

Miller, R.L., Tegen, I., 1998. Climate response to soil dust aerosols. J. Climate 11, 3247-3267. http://dx.doi.org/10.1175/1520-0442(1998)011<3247:CRTSDA>2.0. $\mathrm{CO} ; 2$.

Moore, J.K., Doney, S.C., Glover, D.M., Fung, I.Y., 2002. Iron cycling and nutrientlimitation patterns in surface waters of the world ocean. Deep-Sea Res. Part 2, Top. Stud. Oceanogr. 49, 463-507. http://dx.doi.org/10.1016/S09670645(01)00109-6.

Muhs, D.R., Prospero, J.M., Baddock, M.C., Gill, T.E., 2014. Identifying sources of Aeolian mineral dust: present and past. In: Stuut, J.B., Knippertz, P. (Eds.), Mineral Dust: A Key Player in the Earth System. Springer, pp. 1-509.

Nagashima, K., Tada, R., Tani, A., Sun, Y., Isozaki, Y., Toyoda, S., Hasegawa, H., 2011. Millennial-scale oscillations of the westerly jet path during the last glacial period. J. Asian Earth Sci. 40, 1214-1220. http://dx.doi.org/10.1016/j.jseaes. 2010.08.010.

Otto-Bliesner, B.L., Schneider, R., Brady, E.C., Kucera, M., Abe-Ouchi, A., Bard, E., Braconnot, P., Crucifix, M., Hewitt, C.D., Kageyama, M., Marti, O., Paul, A., RosellMelé, A., Waelbroeck, C., Weber, S.L., Weinelt, M., Yu, Y., 2009. A comparison of PMIP2 model simulations and the MARGO proxy reconstruction for tropical sea surface temperatures at last glacial maximum. Clim. Dyn. 32, 799-815. http://dx.doi.org/10.1007/s00382-008-0509-0.

Pourmand, A., Dauphas, N., 2010. Distribution coefficients of 60 elements on TODGA resin: application to $\mathrm{Ca}, \mathrm{Lu}, \mathrm{Hf}, \mathrm{U}$ and Th isotope geochemistry. Talanta 81 , 741-753. http://dx.doi.org/10.1016/j.talanta.2010.01.008.
Pourmand, A., Dauphas, N., Ireland, T.J., 2012. A novel extraction chromatography and MC-ICP-MS technique for rapid analysis of REE, Sc and Y: revising CI-chondrite and Post-Archean Australian Shale (PAAS) abundances. Chem. Geol. 291, 38-54. http://dx.doi.org/10.1016/j.chemgeo.2011.08.011.

Pourmand, A., Marcantonio, F., Schulz, H., 2004. Variations in productivity and eolian fluxes in the northeastern Arabian Sea during the past $110 \mathrm{ka}$. Earth Planet. Sci. Lett. 221, 39-54. http://dx.doi.org/10.1016/S0012-821X(04)00109-8.

Pourmand, A., Prospero, J.M., Sharifi, A., 2014. Geochemical fingerprinting of transAtlantic African dust based on radiogenic $\mathrm{Sr}-\mathrm{Nd}-\mathrm{Hf}$ isotopes and rare earth element anomalies. Geology 42, 675-678. http://dx.doi.org/10.1130/G35624.1.

Prospero, J.M., Ginoux, P., Torres, O., Nicholson, S.E., Gill, T.E., 2002. Environmental characterization of global sources of atmospheric soil dust identified with the NIMBUS 7 Total Ozone Mapping Spectrometer (TOMS) absorbing aerosol product. Rev. Geophys. 40, 1-31. http://dx.doi.org/10.1029/2000RG000095.

Psomiadis, D., Ghilardi, M., Demory, F., Delanghe-Sabatier, D., Bloemendal, J., Yiu, C., 2014. Late Pleistocene to Mid-Holocene landscape reconstruction in the western part of the Thessaloniki Plain, Greece: evidence for environmental changes, and implications for human occupation. Z. Geomorphol. Suppl. Issues 58, 67-87. http://dx.doi.org/10.1127/0372-8854/2013/S-00137.

Rossignol-Strick, M., 1995. Sea-land correlation of pollen records in the Eastern Mediterranean for the glacial-interglacial transitions: biostratigraphy versus radiometric time-scale. Quat. Sci. Rev. 14, 893-915.

Rossignol-Strick, M., 1999. The Holocene climatic optimum and pollen records of sapropel 1 in the eastern Mediterranean, 9000-6000 BP. Quat. Sci. Rev. 18, 515-530.

Scheuvens, D., Schütz, L., Kandler, K., Ebert, M., Weinbruch, S., 2013. Bulk composition of northern African dust and its source sediments - a compilation. Earth-Sci. Rev. 116, 170-194. http://dx.doi.org/10.1016/j.earscirev.2012.08.005.

Schiemann, R., Lüthi, D., Schär, C., 2009. Seasonality and interannual variability of the westerly jet in the Tibetan Plateau region. J. Climate 22, 2940-2957. http://dx.doi.org/10.1175/2008JCLI2625.1.

Shao, Y., Wyrwoll, K.-H., Chappell, A., Huang, J., Lin, Z., McTainsh, G.H., Mikami, M., Tanaka, T.Y., Wang, X., Yoon, S., 2011. Dust cycle: an emerging core theme in Earth system science. Aeolian Res. 2, 181-204. http://dx.doi.org/10.1016/ j.aeolia.2011.02.001.

Sharifi, A., Pourmand, A., Canuel, E.A., Ferer-Tyler, E., Peterson, L.C., Aichner, B. Feakins, S.J., Daryaee, T., Djamali, M., Beni, A.N., Lahijani, H.A.K., Swart, P.K., 2015. Abrupt climate variability since the last deglaciation based on a highresolution, multi-proxy peat record from NW Iran: the hand that rocked the Cradle of Civilization? Quat. Sci. Rev. 123, 215-230. http://dx.doi.org/10.1016/j. quascirev.2015.07.006.

Sirocko, F., Garbe-Schönberg, D., Devey, C., 2000. Processes controlling trace element geochemistry of Arabian Sea sediments during the last 25,000 years. Glob. Planet. Change 26, 217-303. http://dx.doi.org/10.1016/s0921-8181(00)00046-1.

Stein, A.F., Draxler, R., Rolph, G.D., Stunder, B.J.B., Cohen, M.D., Ngan, F., 2016. NOAA's HYSPLIT atmospheric transport and dispersion modeling system. Bull. Am. Meteorol. Soc. 96, 2059-2077. http://dx.doi.org/10.1175/BAMS-D-14-00110.1.

Tegen, I., Lacis, A., 1996. Modeling of particle size distribution and its influence on the radiative properties of mineral dust aerosol. J. Geophys. Res. 101, 19237-19244

Tierney, J.E., Russell, J.M., Huang, Y., Damsté, J.S.S., Hopmans, E.C., Cohen, A.S. 2008. Northern hemisphere controls on tropical southeast African climate during the past 60,000 years. Science 322, 252-255. http://dx.doi.org/10.1126/ science. 1160485.

Zhao, W., Sun, Y., Balsam, W., Lu, H., Liu, L, Chen, J. Ji, J., 2014. Hf-Nd isotopic variability in mineral dust from Chinese and Mongolian deserts: implications for sources and dispersal. Sci. Rep. 4 (5837), 1-6. http://dx.doi.org/10.1038/ srep05837. 